\title{
DO ENTREPRENEURIAL DYNAMICS AND EMPLOYMENT INFLUENCE ECONOMIC GROWTH? EVIDENCE FOR ROMANIA
}

\author{
Ramona Simut ${ }^{1}$, Alina Badulescu ${ }^{2}$, Dragos Dianu ${ }^{3 *}$ \\ 1,2 Department of Economic and Business, Faculty of Economic Sciences, University of \\ Oradea, Oradea, Romania \\ ${ }^{3}$ Doctoral School of Economics, University of Oradea, Oradea, Romania \\ simut.ramona@yahoo.com \\ abadulescu@uoradea.ro \\ dianudragos@yahoo.com
}

\begin{abstract}
The literature on the relationship between entrepreneurship, firm formation and economic development often describes entrepreneurship as a complex phenomenon, led by individuals, embedded in a broad economic and societal context, which, in regional terms, influences the quality and results of the entrepreneurial process. From a micro-economic perspective, the region is shaped by the myriad of laborious and innovative actions of entrepreneurs, looking for opportunities, taking risks, starting businesses and generating economic and social associations. Competition, trust, networks, mentalities, the education system, public policies, all are ingredients that can provide opportunities for many actors at the local level (institutions, businesses, population, etc.) and thus, for the region as a whole to thrive. Often these elements can offer the opportunities of economic convergence between regions and countries. On the other hand, we found that the potential of entrepreneurship to generate benefits and an impetus for the economic growth of regions were not fully researched and understood, despite suggestive empirical evidence and a rich literature in regional studies. In this article we analysed, at the level of the 8 development regions of Romania, the relation between the firm's formation and the evolution of the Gross Domestic Product, respectively the relation between employment/active population and the evolution of the Gross Domestic Product. We did not find clear evidence that the pace of setting up new businesses has a certain effect on economic growth or employment, but we found that in some regions, better equipped in terms of infrastructure, qualification and diversity of human capital, entrepreneurial dynamics could moderately influence the positive evolution of these macroeconomic indicators.
\end{abstract}

Keywords: firm's formation, discontinuity; GDP; active population; Romania, development regions.

JEL classification: O18, L26, R11.

\section{Introduction}

In the literature of the last decades, entrepreneurship has gained a well-defined position in economic theory, assigning it a critical role in economic growth. It can be considered a fundamental, renewable resource, but depending on investment in education or quality of governance, its performance being uneven and dependent on certain characteristics of

\footnotetext{
* Corresponding author: Dragos Dianu Cite as:

Simut, R, Badulescu, A., and Dianu, D. 2021. Do Entrepreneurial Dynamics Influence Economic Growth and Employment? Evidence for Romania. Oradea Journal of Business and Economics, 6(2), pp. 98-110. http://doi.org/10.47535/1991ojbe133
} 
human societies, and unpredictable in time and space. Entrepreneurship is often linked with the prosperity of a society, but the concept and connection are somewhat vague, the definitions of experts, from different fields and periods of time, being diverse and challenging. In the literature on this topic, entrepreneurship is a complex phenomenon, led by individuals, but embedded in a broader economic and societal context, and in spatial terms, the regional context determines the quality and results of the entrepreneurial process. Theory and practice revealed a variety of challenges, areas of study and action for researchers, practitioners, and decision makers. It is a field in which industrial organization, cultural geography, locations theory, business economics and technological innovation create strong and constantly changing links. From a macroeconomic or global perspective, the region is a strategic element in a process of global development, meanwhile, from a micro-economic perspective, the region is shaped by innovative actions of entrepreneurs who seek opportunities, undertake risks and initiate business, stimulating new economic and social relations.

Nowadays, the main concerns of regions and local communities refer to the discovery of new ways of encouraging and supporting local development, by the incentivizing of entrepreneurship and the setting up new firms (or the support of existing ones). Literature considers that free initiative, entrepreneurship, innovation and the energy of setting up large numbers of small and medium-sized enterprises (SMEs) are an essential force in ensuring economic growth, balanced development of regions, mitigating the crisis of rural communities and unemployment, increasing revenues for local and national budgets, enhancing creativity and avoiding the depopulation of small communities (Acs \& Armington, 2004).

On the other hand, this solid trust in the potential and the nuances of entrepreneurship in solving worldwide economic and social problems has generated a dispute between those who support the entrepreneurial dependence by environment (an entrepreneurship influenced by education, culture, social support systems, technology, the presence of human capital) and those who consider that entrepreneurial behavior is highly individualized and is able to overcome the social and regional conditioning in which it appears. The mainstream of academics, practitioners and supporters of free initiative, but especially the representatives of local and regional communities, agree that favorable economic, social and cultural conditions must be created (Davidsson, 1995; Aoyama, 2009), and that the presence of human capital (Acs and Armington, 2004), the availability of financial resources (Audretsch \& Keilbach, 2004), (Usman et al, 2019), the capacity to learn and nurture creativity (Florida, 2007), will lead to the flourishing of entrepreneurship and the creation of new SME's, and thus will commit to the development of communities and regions. Even so, by understanding entrepreneurship as being a highly contextual phenomenon we cannot ignore the individualistic features of the entrepreneur and its ability to shape the economic and social environment in which they develop. Carried by a highly popular wave that assigns entrepreneurship and the SME sector as having universal solutions to modern world issues, stimulated by the huge financial resources allocated to the cohesion and socio-economic convergence of the regions (as in the case of the EU), scholars and policy makers ignore, or tacitly accept, a series of threats. Some of them stem from the extremely diverse nature of social and economic inequalities. Others are based in the unique and contextual nature of entrepreneurship and, that is possible that private initiative and the evolution of entrepreneurship to occur and manifest themselves in different directions and generate unequal and unsatisfactory results between regions (Fritsch \& Mueller, 2008) between urban areas, or between developed and developing countries respectively. 


\section{Brief theoretical overview on entrepreneurship and regional development}

Theories about the role of the regional context and regional entrepreneurial and innovation systems have been rapidly adopted in recent years, both in scientific areas and in political and economic decisions, strengthened by the contributions of Michael Porter (1990), (2000) on the determinants of competitive advantage in firms and nations, and, respectively, by regional theories on the advantages of location and industrial districts (Krugman, 1991; Becattini, 1990). Porter's model (1990) argues that the most important factors shaping the competitive advantages of nations and regions are: 1 . The presence of related and support industries, 2 . The availability and quality of factors of production, 3. Domestic demand and market opportunities 4 . The structure of the economy (cooperation between firms, intraindustry rivalry, the wider economic landscape of the national or regional economy).

Although Porter's model was developed to explain the competitive advantage of some nations over others, in recent decades it has also been used to analyse regional economic structures, combined with the externalities of Marshallian industrial districts (labour, collaboration between similar companies along the value chain) (Becattini, 1990) and dynamic externalities (learning and knowledge) (Audretsch, 2003).

Porter's contribution is to urge us to look beyond individual industrial sectors (as defined by NACE codes) to understand regional economic dynamics, and that interactions between sectors matter for regional economic growth. In other words, the theory developed around these concepts insists on the dynamic role of the national and regional economy and emphasizes the chance of creating and exploiting the synergy between industrial sectors, knowledge dissemination, synergies in productions and learning effects.

Some questions arise: what kind of regional externalities are most important for entrepreneurship to contribute to regional development, and how can we distinguish to strengthen the positive effects and temper the negative consequences, how to turn the entrepreneurial context from a passive opportunity provider, into an active agent of development (Acs, et al., 2014; Johannisson, 1993)? How can we determine companies to approach and make connections to specialized resources, such as qualified people, companies and institutions, support structures (Szerb, et al., 2013), beyond the access to vital resources (financial capital, customers, distribution channels, human capital, essential services, etc.)? The diversity and availability of specialized resources can shape the support provided to entrepreneurs and can differentiate between intra- and inter-regional performance.

Most studies highlight the key role of personal initiative and motivation in business creation and development, but also that the entrepreneurship is dependent upon the wider economic and social context (Acs, et al., 2014; Badulescu, 2010). In regional terms, researchers have identified numerous factors, such as income levels, education and qualifications, infrastructure, legislation, social cohesion etc. which can both increase or diminish the effects and importance of personal initiative (Fritsch, 2008; Acs, et al., 2014, Fritsch \& Wyrwich, 2017). Understanding the role and benefits that entrepreneurship activities have upon the economy and society also requires a multi-dimensional approach, which can also capture certain qualitative aspects, such as creativity, innovation, intensive use of technology, value creation and growth potential, environmental and institutional factors etc. (see Figure 1). Starting from the idea that there is a certain lag between when an enterprise is created and uncovering the effects on productivity and regional GDP increase, Dejardin (2011), in a study on Belgian regions, claims that the net firms' entry could play an important role in explaining regional economic growth. Also, he points out that the most important and visible effects appear in the service sectors and are less visible in the manufacturing (production) sectors (Dejardin, 2011). Moreover, Fritsch (2008) has introduced a dynamic aspect explaining these influences, proving that ripple effects do not refer only to a time lag between the creation of an enterprise and recognizing its outcomes. 


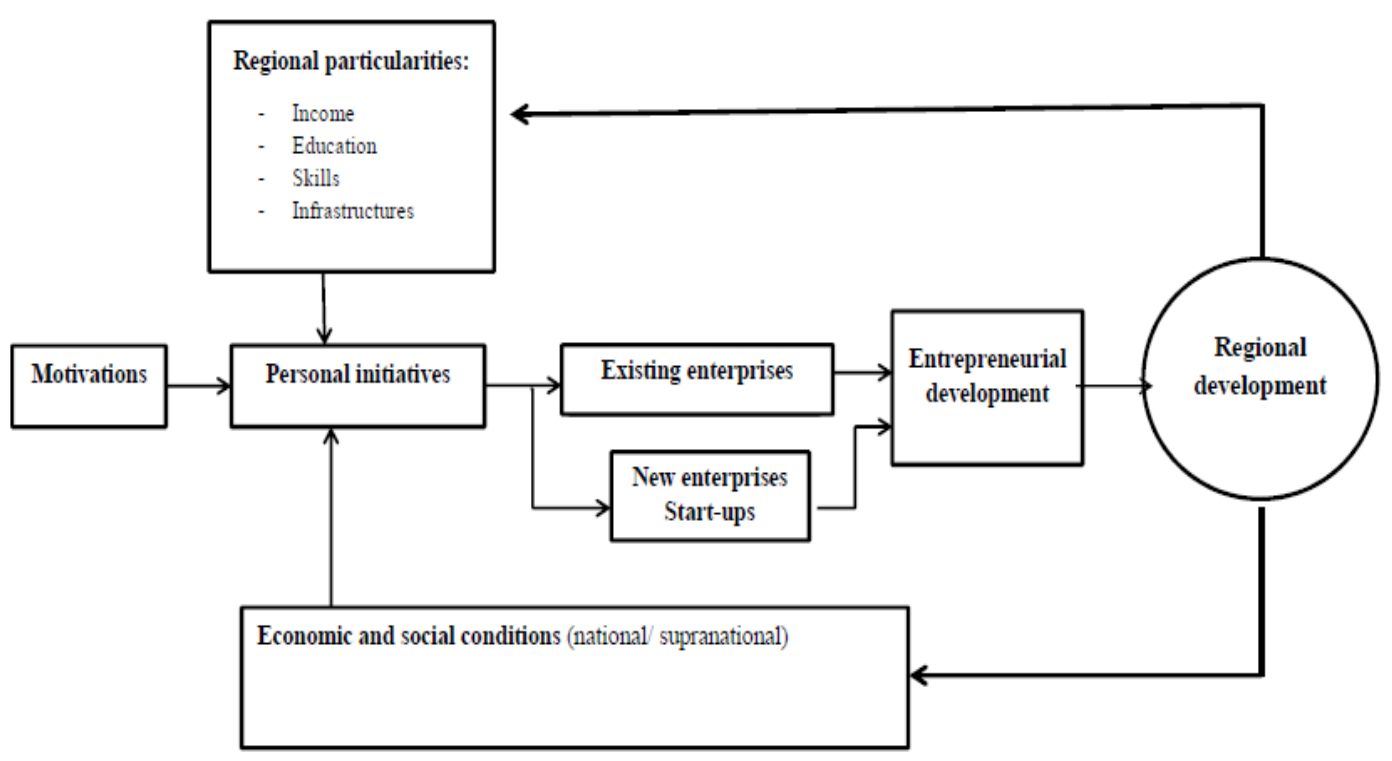

Figure 1: Interaction between private initiative, national factors and regional particularities in regional and local development

Source: own elaboration based on Fritsch and Wyrwich (2017) and Acs and Armington (2004).

Another challenge for regional or national entrepreneurial dynamism concerns understanding the relationship between new business creation and growth: either as a source or as a consequence of economic growth. Although much of public policy, common perception and a part of economic theory support the idea that setting up of new companies supports economic growth, Shane (2008) and Meza and Southey (1996) claim that there aren't enough arguments to support the idea that the creation of new enterprises generates economic growth, and that "rather, economic growth probably causes people to start businesses" (Shane, 2008, p. 2). Their research, conducted on a large number of countries and over great lengths of time, suggests that "firm formation" tends to be quite modest and even declines as countries become more economically prosperous. Thus, the authors have stated that there is no long-term statistical correlation between the formation rate of new enterprises and the increase of number of employees in a given territorial profile, but a relatively constant ratio among regions between the number of enterprises and the territorial population. In other words, there is a slowing down of the rate of forming new enterprises in more developed regions, together with a more sustained pace in regions with fewer newly created enterprises.

\section{Regions and entrepreneurial dynamics: objectives, challenges and strategies}

The analysis of entrepreneurial dynamics takes into consideration two different concepts: the analysis of figures pertaining to business formation, growth, churn and survival, and, respectively, the information regarding competitiveness, i.e. how we understand and measure productivity, innovation potential and the degree of openness of new enterprises (CREC, 2017). 
There are a variety of objectives pursued by regions and local communities in economic development policies. Some regions focus on simple quantitative targets, such as increasing the number of entrepreneurs, start-ups, and jobs created, while others on precise objectives, outlined by a certain profile of the company (companies) / jobs / or entrepreneur (frequently "creative") desired in the respective area. Finally, there are quantifiable "output" regional objectives - production, deliveries of goods and services in / from that region.

Although all these objectives can be rational and achievable, it is recommended for these objectives to be defined and adjusted according to the expectations and resources allocated and to be more results-oriented. Also, the vitality of entrepreneurial ecosystems (national, regional, community) depends on other elements, such as funding for research and development in universities, available investment capital, number and qualification of people with higher technical education, patents or technological licenses obtained in (local) universities or research centres, etc., which are associated with a certain type of entrepreneurial activity and better anticipate the qualitative results that are pursued (Stangler \& Bell-Masterson, 2015).

Regions, be them rural or urban, present themselves with certain concerns. First of all, regions fear that they will be ignored or that they will be granted a secondary importance. Secondly, high "death" rate of companies (even in high-edge development sectors), especially in the first two years of existence, raises the problem of long-term viability for a vast majority of jobs. Regions and decision-making factors should not concentrate exclusively on attracting only high-tech or well-known companies. Economic diversity can diminish the impact of an economic recession (that could be devastating for the regions only focused on singular/unique industries) and ensure complementary and diverse employment conditions. Entrepreneurial performance and economic prosperity are based on a general continuity of successes, successes that are built upon long term logical and healthy economic principles. We must accept the fact that entrepreneurial or corporate success is not permanent, by rather temporary and irregular (Gavrilut et al., 2019). We must be aware that each economy is cyclical, and that turbulences, expansions, contractions and the disruption of industries will always exist, and that the most affected component is and will be employment. In the case of entrepreneurs, economic measures must lead to the regaining of trust in themselves as entrepreneurs and to rediscover their entrepreneurial spirit. Quick recovery and regaining of growth following each episode of a crisis thus requires attention and preparedness and these should be part of the concerns of political decision makers and of representatives of communities.

\section{Regional outlook on Romania}

In Romania, at $1^{\text {st }}$ of July 2020 , out of 1.08 million companies, up to 1,02 million are to be considered active (Romanian National Trade Register Office, 2021), approximately 53 active companies for each 1000 individuals (National Institute of Statistics (Romania), 2021a). Compared to the EU average or ECE countries, Romania scores well regarding entrepreneurial efficiency, young business entrepreneurs, Total Early-stage Entrepreneurs (TEA) or entrepreneurial employees' rate, but scores low in respect to innovative capacity (Dézsi-Benyovszki, et al., 2014; Badulescu and Cadar, 2016). This proves that it is not only the number of enterprises that matters, but also, their quality, the sectors in which they operate, their innovative potential, the net results, and last but not least, their geographic distribution. Romania, alongside Croatia, Hungary, Lithuania and Poland currently position themselves as being efficiency driven economies. Approximately $31 \%$ of the entrepreneurial actions tend to be focused towards the transformational sector, and roughly a quarter of entrepreneurs use new technologies (Dézsi-Benyovszki, et al., 2014). Both on the short and long term, efficiency as regards the economics of regions is necessary, but a transition from an efficiency-based economy to an innovation-based economy is vital; what is more, 
developments in the higher education sector and the proper functioning of the labor market are elements that have to be dealt with before achieving the aforementioned transition. Even so, in recent years, we have seen that some regions or counties from Romania have developed and evolved at higher rates than other regions. This in turn should lead to increased labor force churn in these areas, given an increased income potential.

\section{Methodology, results and discussion}

Starting from the idea that the dynamics of the emergence and discontinuation of firms as well as of the active population should be reflected in the dynamics of the GDP (Simut et al., 2019), we have tried to statistically demonstrate the existence and the meaning of these relations in the case of the 8 development regions (EU-NUTS-2) of Romania. The data was obtained from the official web pages of the Romanian National Institute of Statistics (for the active population, price indices, GDP) and the Romanian National Trade Register Office (for registrations and discontinuations of enterprises), for the years 2004-2018 (see Tables 4 and 5 in Annexes). To test the hypothesis, we have used the Pearson correlation coefficient and the Pearson correlation ratio.

The study of the correlation between enterprise registrations and GDP (Table 1) indicates the existence of strong (and almost functional) negative correlations between the company registrations and the GDP, both regional and national Romanian level. The weakest (negative) relation refers to the South West region $(-0.0101)$, followed by the North-West region (-0.1643). At least apparently, the results do not confirm our initial assumption that the new firms' formation influences GDP growth. Table 4 and Table 5 (Annexes) also show that 2005 was a year of "optimism" as regards the setting up of new firms throughout the studied period, both at regional and country level. As exception, we mention the BucharestIlfov Region (in 2007), and the South West Region respectively (in 2012). We do consider that the large number of registered companies is not reflected in an immediate increase in GDP level, this at least in part due to the fact that these new registrations are actually firms at the beginning of an (yet to be efficient) economic activity, often marked by the lack of experience of the entrepreneur, having a reduced activity, few or no employees. Thus, their impact on GDP would occur only a few years following their registration. There is also the possibility of data distortions, where the place of registration is different from the main activity location etc. 
Table 1: The analysis of the correlations between the number of registered and discontinued companies, the active population, and the GDP, by region and country total (2004-2018)

\begin{tabular}{|c|c|c|c|c|c|c|}
\hline \multicolumn{7}{|c|}{$\begin{array}{l}\text { Dependent variable: Gross Domestic product- GDP } \\
\text { Period: 2004-2018 (annual data) }\end{array}$} \\
\hline \multirow[t]{4}{*}{ Simple linear $r$} & ession & & & & & \\
\hline & \multicolumn{6}{|c|}{ Independent variable } \\
\hline & \multicolumn{2}{|c|}{$\begin{array}{l}\text { Number of registered } \\
\text { companies (NRC) }\end{array}$} & \multicolumn{2}{|c|}{$\begin{array}{c}\text { Number of } \\
\text { discontinued } \\
\text { companies (NDC) }\end{array}$} & \multicolumn{2}{|c|}{$\begin{array}{l}\text { Employment } \\
\text { (EMP) }\end{array}$} \\
\hline & $r$ & $\begin{array}{c}\mathrm{R}- \\
\text { squared }\end{array}$ & $\mathrm{R}$ & $\begin{array}{c}\mathrm{R}- \\
\text { squared }\end{array}$ & $r$ & $\begin{array}{c}\mathrm{R}- \\
\text { squared } \\
\end{array}$ \\
\hline $\begin{array}{l}\text { Bucharest-Ilfov } \\
\text { (B) }\end{array}$ & -0.4418 & 0.1952 & 0.1899 & 0.0361 & 0.6624 & 0.4388 \\
\hline Center (C) & -0.7122 & 0.5072 & 0.1953 & 0.0381 & -0.6566 & 0.4311 \\
\hline $\begin{array}{l}\text { North-East } \\
\text { (NE) }\end{array}$ & -0.6412 & 0.4111 & -0.0693 & 0.0048 & 0.3239 & 0.1049 \\
\hline $\begin{array}{l}\text { North-West } \\
\text { (NW) }\end{array}$ & -0.1643 & 0.0270 & 0.1289 & 0.0166 & -0.0783 & 0.0061 \\
\hline South (S) & -0.3944 & 0.1556 & 0.0206 & 0.0004 & -0.7919 & 0.6271 \\
\hline $\begin{array}{l}\text { South-East } \\
\text { (SE) }\end{array}$ & -0.6715 & 0.4509 & 0.0329 & 0.0011 & -0.8250 & 0.6806 \\
\hline $\begin{array}{l}\text { South-West } \\
\text { (SW) }\end{array}$ & -0.0101 & 0.0001 & 0.2328 & 0.0542 & -0.7014 & 0.4920 \\
\hline West $(\mathrm{W})$ & -0.4948 & 0.2448 & 0.1378 & 0.0190 & -0.6854 & 0.4698 \\
\hline Total & -0.5172 & 0.2675 & 0.1138 & 0.0130 & -0.5148 & 0.2650 \\
\hline
\end{tabular}

Source: own elaboration based on National Institute of Statistics (Romania), 2021b)

The study of the correlation between discontinued companies and GDP (Table 1) shows the existence of positive, but weak links between discontinued companies and GDP, both regional and national levels. The strongest (relative) association can be found in the South West Region (0.2328), followed by the Center region (by 0.1953). The statistical data (National Institute of Statistics (Romania), 2021b) pinpoints that 2010 was the year with the highest number of discontinuations, both at national and regional level, exceptions being the Bucharest-Ilfov and South-East regions (where this year was, in both cases, 2006). Even so, 2010 still remains a year of significant firms' discontinuation in the Trade Registry throughout the analysed period. The existence of a direct correlation, albeit relatively weak, can be attributed to the fact that that the owners of the non-performing or inactive firms have decide to close them down, either for fiscal reasons or because of the opportunity or need. Except for several tax or legislative measures that can be documented, we are cautious when considering opportunistic, personal or circumstantial reasons as being the genuine motives for the closure peak 2010. We remain at the idea that the "natural" discontinuation of enterprises, far from denoting a negative phenomenon or the sign of an imminent economic collapse, can lead to a better knowledge of the economic environment, of the real number of active firms that contribute to the development and evolution of the GDP. In other words, these discontinuations are, in large part, a removal of the excess of inactive, insignificant economic, formal firms (many established in periods of economic euphoria, by economically unexperienced individuals).

When studying the correlation between the active population and the GDP (Table 1), we have observed contradictory links both regional and national levels. For the Bucharest-Ilfov Region we have noticed a strong, almost functional link between the active population and 
the GDP, with a value of 0.6624 , followed by the North East Region, with a strong but yet weaker link, with the value of 0.3239 . The results for the other regions and country total suggest that there are weak, opposite correlation between the active population and GDP. We could presume either that the Bucharest-Ilfov and North East regions attract more of the active population resources from other regions, or that the structure of the active population (considering their respective qualifications and occupations) is more advantageous for the Bucharest-Ilfov and North East regions. However, further proof of these explanations is necessary. The weakest, and also negative, link between the active population and GDP is found in the North West region (- 0.0783).

In order to increase the significance of the results that determine the impact that the dynamics of the firms' registration and discontinuation as well as the impact of the dynamics of the active population on the GDP in Romania's regions, we will investigate the stationarity, using the Augmented Dickey Fuller test.

Table 2: Unit root test results (ADF test)

\begin{tabular}{|l|c|c|c|c|c|c|c|c|}
\hline \multicolumn{10}{|c|}{ ADF (level) - p-value } \\
\hline & B & C & NE & NW & S & SE & SW & W \\
\hline GDP & 0.96 & 0.98 & 0.66 & 0.99 & 0.91 & 0.46 & 0.98 & 0.95 \\
\hline NRC & 0.27 & 0.33 & 0.21 & 0.13 & 0.25 & 0.20 & 0.07 & 0.38 \\
\hline NDC & 0.01 & 0.01 & 0.02 & 0.01 & 0.04 & 0.00 & 0.05 & 0.01 \\
\hline EMP & 0.03 & 0.97 & 0.13 & 0.52 & 0.66 & 0.97 & 0.70 & 0.91 \\
\hline \multicolumn{8}{|c|}{ ADF (first difference) - p-value } \\
\hline GDP & 0.02 & $<0.10$ & 0.10 & $<0.10$ & 0.01 & 0.03 & $<0.10$ & 0.07 \\
\hline NRC & 0.01 & 0.00 & 0.00 & 0.00 & 0.00 & 0.00 & 0.00 & 0.01 \\
\hline NDC & - & - & - & - & - & - & - & - \\
\hline EMP & - & 0.05 & 0.01 & 0.05 & 0.05 & 0.04 & 0.03 & 0.02 \\
\hline
\end{tabular}

Source: authors' estimates using Eviews

Augmented Dickey-Fuller test results indicate that the null hypothesis is rejected at the $5 \%$ level of significance after the first difference for most of the variables in all region. Because all these variables have a unit root and are stationary at the first difference, we will used log transformation. 
Table 3: The estimation of multiple linear regression in each region

\begin{tabular}{|c|c|c|c|c|c|c|c|c|}
\hline \multirow{2}{*}{\multicolumn{9}{|c|}{$\begin{array}{l}\text { Dependent variable: Gross Domes } \\
\text { Period: } 2004-2018 \text { (annual data) } \\
\text { Multiple linear regression }\end{array}$}} \\
\hline & & & \\
\hline & $B$ & C & $\mathrm{NE}$ & NW & $\mathrm{S}$ & SE & SW & $\mathrm{W}$ \\
\hline Intercept & - & $\begin{array}{l}60.42 \\
(0.00)\end{array}$ & $\begin{array}{l}17.96 \\
(0.08)\end{array}$ & $\begin{array}{l}-81.71 \\
(-2.05)\end{array}$ & $\begin{array}{l}95.98 \\
(0.00)\end{array}$ & $\begin{array}{l}66.28 \\
(0.00)\end{array}$ & $\begin{array}{l}60.46 \\
(0.02)\end{array}$ & $\begin{array}{l}67.12 \\
(0.00)\end{array}$ \\
\hline $\begin{array}{l}\text { NRC } \\
\text { (p-value) }\end{array}$ & $\begin{array}{l}-1.72 \\
(0.00)\end{array}$ & $\begin{array}{l}-2.40 \\
(0.00)\end{array}$ & $\begin{array}{l}-2.50 \\
(0.00)\end{array}$ & $\begin{array}{c}-1.88 \\
(-2.80)\end{array}$ & $\begin{array}{l}-0.70 \\
(0.10)\end{array}$ & $\begin{array}{l}-1.88 \\
(0.00)\end{array}$ & & $\begin{array}{l}-2.50 \\
(0.00)\end{array}$ \\
\hline $\begin{array}{l}\text { NDC } \\
\text { ( } p \text {-value) }\end{array}$ & - & - & - & $1-x_{1}$ & - & 10,1 & $\begin{array}{c}0.21 \\
(0.10)\end{array}$ & - \\
\hline $\begin{array}{l}\text { EMP } \\
\text { ( } p \text {-value })\end{array}$ & $\begin{array}{c}4.09 \\
(0.00)\end{array}$ & $\begin{array}{l}-3.79 \\
(0.05) \\
\end{array}$ & $\begin{array}{l}2.37 \\
(0.09) \\
\end{array}$ & $\begin{array}{l}15.64 \\
(3.00) \\
\end{array}$ & $\begin{array}{l}-10.97 \\
(0.01) \\
\end{array}$ & $\begin{array}{l}-5.37 \\
(0.00) \\
\end{array}$ & $\begin{array}{l}-7.61 \\
(0.04)\end{array}$ & $\begin{array}{l}-4.86 \\
(0.00) \\
\end{array}$ \\
\hline R-squared & 0.63 & 0.77 & 0.55 & 0.72 & 0.52 & 0.74 & 0.43 & 0.78 \\
\hline DW & 0.74 & 1.37 & 1.35 & 1.44 & 0.53 & 1.26 & 0.56 & 1.61 \\
\hline $\begin{array}{l}\text { White } \\
\text { (p-value }\end{array}$ & $\begin{array}{c}1.09 \\
(0.39) \\
\end{array}$ & $\begin{array}{c}1.24 \\
(0.35) \\
\end{array}$ & $\begin{array}{c}0.68 \\
(0.64) \\
\end{array}$ & $\begin{array}{c}1.23 \\
(0.36)\end{array}$ & $\begin{array}{c}0.33 \\
(0.84)\end{array}$ & $\begin{array}{c}0.72 \\
(0.59) \\
\end{array}$ & $\begin{array}{c}0.42 \\
(0.78) \\
\end{array}$ & $\begin{array}{c}0.67 \\
(0.62) \\
\end{array}$ \\
\hline $\begin{array}{l}\mathrm{JB} \\
(p \text {-value. })\end{array}$ & $\begin{array}{l}5.03 \\
(0.08)\end{array}$ & $\begin{array}{c}0.49 \\
(0.78)\end{array}$ & $\begin{array}{l}3.85 \\
(0.14)\end{array}$ & $\begin{array}{c}0.40 \\
(0.81)\end{array}$ & $\begin{array}{c}1.30 \\
(0.52)\end{array}$ & $\begin{array}{l}1.38 \\
(0.50)\end{array}$ & $\begin{array}{l}1.39 \\
(0.49)\end{array}$ & $\begin{array}{c}0.73 \\
(0.69)\end{array}$ \\
\hline
\end{tabular}

Source: authors' estimates using Eviews

The results obtained from applying the multiple linear regression model also show that the NRC (Number of registered companies) negatively influences the GDP in each region, while the NCDs (Number of discontinued companies) in the South-West regions have a positive impact on GDP. In what concerns the testing of the fundamental hypothesis regarding the errors of the model, we can conclude that the homoscedasticity of the residual variable hypothesis is confirmed, as the probability related to the Fisher statistic is higher than 0.05 . Also, the independence of the residual variable hypothesis is confirmed in five regions, since the Durbin Watson statistic is greater than the critical value $d_{2}=1.26$ and lower than $4-d_{2}=$ 2.74. Because the error independence hypothesis is not verified, to eliminate the phenomenon of autocorrelation we will use in the following studies the Cochrane-Orcutt method. The Jarque-Berra test confirmed the normality hypothesis, as the associated probability of accepting the null hypothesis is larger than 0.05 .

\section{Conclusions}

In order to understand more clearly how firms' dynamics and entrepreneurship contributes to economic and societal development, it is important to recognize the quality of entrepreneurial actions and behaviors in national, regional, community, urban contexts etc. The focus on regions has several explanations - first of all, most of (entrepreneurial) enterprises are set up, operate, develop and creates networks locally or regionally. By default, they take over (and, reciprocally, induce) local or regional contextual influences. Second, significant variations in industrial structures and differences in economic achievement between regions can also be understood through regional firms' concentration and entrepreneurial performance. In this paper we have tried to analyze, in the case of development regions (NUTS 2) of Romania, to what extent, the dynamics of firms 'settingup and discontinuation, should be reflected in the dynamics of GDP.

Across Romanian regions, with respect to registrations and discontinuations of companies, even if scores tend to be quite similar, we didn't find a homogenous framework, that all 
regions are similar and more or less of same attractiveness, performance, innovation and preparedness levels. In this paper we have aimed to address how firm formation and discontinuity is related to national and regional development, as well as the impact of these entrepreneurial developments on the active population and net investments in the economy. We have found that between the formation of new enterprises and GDP dynamics, strong, direct relationships cannot be proven, thus we cannot unequivocally voice out that the setting up of new businesses stimulates GDP growth. There are also weak and unconvincing correlations between the pattern of firm discontinuation and the evolution of GDP. We may consider that new enterprises have limited prospects that could not influence GDP, especially in their first few years of existence. In the case of discontinuations, by analysing the specific periods in which they had more accelerated rhythms and by interpreting this in connection with changes in the fiscal and legal frameworks, we can better explain the evolution of this indicator. Consequently, the correlations between SME dynamics and GDP dynamics are quite questionable (Gavrilut et al., 2019). We have noticed that there are relatively strong links between entrepreneurial dynamics, GDP and the employed population in some regions (already better placed in terms of economic and social development), which makes us advance the hypothesis that some regions will take advantage of the entrepreneurial dynamism in times of economic growths. Typically, we will see in performing regions an improvement in the structure of the active population as regards qualifications, as well as a higher share of dynamic entrepreneurs with higher education, while in other regions, despite their numbers, enterprises will have mediocre rhythms of growth, and dynamism and entrepreneurial initiative will be uncertain.

Certainly, the potential of entrepreneurship in creating economic and societal benefits and an impetus for the regions' economic growth has not been fully researched and understood, notwithstanding suggestive empirical evidence and a rich literature in regional studies. We consider that, from the perspective of economic development, a multidimensional understanding of entrepreneurship is certainly more appropriate facing new contemporary challenges. In other words, research must go beyond empirical investigations, which use simple dimensions of entrepreneurship such as self-employment rate, SMEs' creation rate, firms with individual private capital ratio, business churn, etc., most of them being onedimension indicators, focused on identifying the population employed (or interested in engaging) in "entrepreneurial" activities. Multidimensional approaches must also focus on the qualitative aspects of entrepreneurship, such as creativity, innovation, knowledge and intensity of technology, value creation, or the orientation towards high growth potential. These approaches take into account different environmental factors, the efficiency and quality of the institutional framework, the quality of education, entrepreneurial traditions and the predisposition to association, etc. More researches, going beyond the quantitative coordinates and focus on qualitative and upgrading aspects, referring the structural trends of the SME sector, are needed.

\section{References}

Acs, Z. and Armington, C. (2004). Employment growth and entrepreneurial activity in cities. Regional Studies, 38 (8), pp. 911-927, doi: 10.1080/0034340042000280938.

Acs, Z., Stam, E., Audretsch, D. and O'Connor, A., 2017. The lineages of the entrepreneurial ecosystem approach. Small Business Economics, 49 (1), pp. 1-10. doi: 10.1007/s11187-017-9864-8.

Acs, Z., Autio, E. and Szerb, L. (2014). National Systems of Entrepreneurship: Measurement issues and policy implications. Research Policy, 43 (3), pp. 476-494. 10.1016/j.respol.2013.08.016.

Aoyama, Y. (2009). Entrepreneurship and regional culture: The case of Hamamatsu and Kyoto, Japan. Regional Studies, 43 (3), 495-512, doi: 10.1080/00343400902777042. 
Audretsch, D., 2003. Entrepreneurship A survey of the literature. Enterprise Papers No. 14, Brussels: Enterprise Directorate-General European Commission.

Audretsch, D. and Keilbach, M. (2004). Entrepreneurship and regional growth: an evolutionary interpretation. Journal of Evolutionary Economics, 14 (5), pp. 605-616, doi: 10.1007/s00191-004-0228-6.

Badulescu, A. (2010). Entrepreneurial Motivations: Are Women Driven by Different Motivators than Men? (II - Some Evidence For EU and Romania). The Annals of the University of Oradea, Economic Sciences Series, XIX (2), pp. 358-364.

Badulescu, D. and Cadar, O. (2016). Romania: Many Entrepreneurs but Few Innovators. The Annals of the University of Oradea. Economic Sciences, XXV (1), pp. 465-475. Becattini, G., 1990. The Marshallian Industrial District as a Socio-Economic Notion. In: G. Becattini, F. Pyke and W. Sengenberger, eds. Industrial Districts and Inter-Firm Cooperation in Italy. Geneva: International Labour Studies, pp. 37-51.

https://doi.org/10.4000/rei.6507.

Center for Regional Economic Competitiveness (CREC), (2017). Redefining Economic Development Performance Indicators for a Field in Transition, CREC, Arlington, VA, USA. Davidsson, P. (1995). Culture, structure and regional levels of entrepreneurship.

Entrepreneurship \& Regional Development, 7 (1), pp. 41-62.

https://doi.org/10.1080/08985629500000003.

Dejardin, M. (2011). Linking net entry to regional economic growth. Small Business Economics, 36 (4), pp. 443-460. https://doi.org/10.1007/s11187-009-9255-x.

Dézsi-Benyovszki, A., Nagy, A. and Szabo, T.-P. (2014). Entrepreneurship in Romania. Country Report 2014, Global Entrepreneurship Monitor.

Florida, R. (2007). Toward the learning region. In: R. Rutten and F. Boekema, ed. The learning region: Foundations, state of the art, future. Edward Elgar, Cheltenham, UK. Fritsch, M. (2008). How does new business formation affect regional development? Introduction to the special issue. Small Business Economics, 30, pp. 1-14. https://doi.org/10.1007/s11187-007-9057-y.

Fritsch, M. and Mueller, P. (2008). The effect of new business formation on regional development over time: The case of Germany. Small Business Economics, 30, pp. 15-29. https://doi.org/10.1007/s11187-007-9067-9

Fritsch, M. and Wyrwich, M. (2017). Persistence of Regional Entrepreneurship: Causes, Effects, and Directions for Future Research, The Jena Economic Research Papers, 2017 003. Friedrich Schiller University, Jena, Germany.

Gavrilut, D., Dianu, D., Badulescu, D., Badulescu A. (2019), Entrepreneurial Dynamics and Regional Economic Development in Romania, The 34th International Business Information Management Association Conference (IBIMA), Madrid, Spain, November 2019.

Johannisson, B., 1993. Designing Supportive Contexts for Emerging Enterprises. In: C. Karlsson, B. Johannisson \& D. Storey, eds. Small Business Dynamics: International, National and Regional Perspectives. London: Routledge, pp. 117-144.

Krugman, P., 1991. Increasing Returns and Economic Geography. Journal of Political Economy, 99, pp. 483-499.

Meza, D. and Southey, C., (1996). The Borrower's Curse: Optimism, Finance and Entrepreneurship. The Economic Journal, 106 (435), pp. 375-386.

National Institute of Statistics (Romania), (2021b). TEMPO ONLINE, http://statistici.insse.ro:8077/tempo-online/\#/pages/tables/insse-table, [accessed August 18, 2021].

National Institute of Statistics (Romania), (2021a). Romania in Figures. Available at https://insse.ro/cms/sites/default/files/field/publicatii/romania in figures $20210 . p d f$, [accessed September 18, 2021].

Porter, M., 1990. The Competitive Advantage of Nations. New York: Free Press. 
Porter, M., 2000. Location, competition, and economic development: Local clusters in a global economy. Economic Development Quarterly, 14 (1), pp. 15-34.

https://doi.org/10.1177/089124240001400105

Romanian National Trade Register Office (2021). Statistics, Available at https://www.onrc.ro/index.php/ro/statistici, [Accessed at August 16, 2021].

Simut, R., Badulescu, D., Stiube, E., Dianu, D (2019). Do Entrepreneurship And Business Formation Generate Economic Growth? A Regional Analysis For Romania, in Proceedings of the International Management Conference, Academy of Economic Studies, Bucharest, Romania, 13 (1), pp. 615-625.

Shane, S. (2008). Why encouraging more people to become entrepreneurs is bad public policy, The Weatherhead School of Management. World Entrepreneurship Forum, Case Western Reserve University, USA. DOI:10.1007/S11187-009-9215-5

Stangler, D. and Bell-Masterson, J., 2015. Measuring an Entrepreneurial Ecosystem, Kansas City, USA: Kauffman Foundation Research Series on City, Metro, and Regional Entrepreneurship. DOI: 10.2139/ssrn.2580336

Usman, S.M., Bukhari, F.A.S., Usman, M., Badulescu, D.; Sial, M.S. (2019), Does the Role of Media and Founder's Past Success Mitigate the Problem of Information Asymmetry? Evidence from a UK Crowdfunding Platform. Sustainability, 11, 692. https://doi.org/10.3390/su11030692.

\section{Bio-notes}

Ramona Simut is Associate Professor at Faculty of Economic Sciences, University of Oradea. She graduated the same University, and her research interest area includes Entrepreneurship, Business Development and Economic Modelling.

Alina Badulescu is Professor of Economics and doctoral supervisor at the Faculty of Economics and Doctoral School in Economics within the University of Oradea, Romania. She graduated Bucharest University of Economic Studies and she has authored and coauthored numerous journal articles and books in the area of Tourism, Entrepreneurship, Microeconomics.

Dragos Dianu graduated Bucharest University of Economic Studies. He is currently Ph.D. student at University of Oradea. His doctoral research is focused on entrepreneurship and regional development. 


\section{Annexes}

Table 4: Gross Domestic Product (GDP), by regional and national level, 2004-2018 (billions of RON, current prices)

\begin{tabular}{|c|c|c|c|c|c|c|c|c|c|c|c|c|c|c|c|}
\hline Regions & 2004 & 2005 & 2006 & 2007 & 2008 & 2009 & 2010 & 2011 & 2012 & 2013 & 2014 & 2015 & 2016 & 2017 & 2018 \\
\hline Bucharest-Ilfov & 53.3 & 69.4 & 81.1 & 102.7 & 141.5 & 131.1 & 133.0 & 147.1 & 158.7 & 171.4 & 179.0 & 197.8 & 207.6 & 232.8 & 256.5 \\
\hline Center & 29.0 & 32.8 & 39.9 & 50.5 & 60.7 & 60.5 & 60.3 & 62.1 & 67.5 & 70.2 & 73.3 & 78.8 & 86.6 & 96.9 & 108.3 \\
\hline North-East & 28.8 & 32.5 & 38.1 & 46.1 & 57.2 & 57.1 & 56.6 & 56.5 & 61.2 & 65.1 & 67.2 & 71.5 & 77.2 & 88.8 & 98.7 \\
\hline North-West & 29.6 & 34.1 & 41.2 & 51.2 & 61.5 & 61.4 & 60.4 & 61.1 & 67.4 & 71.3 & 76.6 & 81.7 & 90.1 & 104.8 & 114.6 \\
\hline South & 32.2 & 36.7 & 44.1 & 52.8 & 67.4 & 69.4 & 65.7 & 73.1 & 70.7 & 77.3 & 86.9 & 86.6 & 93.7 & 100.9 & 112.1 \\
\hline South-East & 29.5 & 33.0 & 39.1 & 46.0 & 55.8 & 56.1 & 56.3 & 61.7 & 64.4 & 71.6 & 75.3 & 76.2 & 79.9 & 87.9 & 97.7 \\
\hline South -West & 21.6 & 23.5 & 28.3 & 34.0 & 41.9 & 42.3 & 41.9 & 41.9 & 46.2 & 47.8 & 48.4 & 52.1 & 55.3 & 63.9 & 73.2 \\
\hline West & 24.6 & 28.4 & 35.0 & 42.1 & 53.4 & 52.6 & 53.4 & 55.2 & 57.3 & 60.2 & 61.4 & 67.4 & 74.2 & 80.8 & 89.3 \\
\hline Total & 248.7 & 290.5 & 347.0 & 425.7 & 539.8 & 530.9 & 528.2 & 559.2 & 593.7 & 635.5 & 668.6 & 712.6 & 765.1 & 85.7 & 95.1 \\
\hline
\end{tabular}

Source: National Institute of Statistics (Romania), 2021b. TEMPO ONLINE. Available at: http://statistici.insse.ro:8077/tempo-online/\#/pages/tables/inssetable, [Accessed at 18.08.2021]. Note: RON- National Romanian currency

Table 5: Number of new company registrations, for regional and national Romanian level, during 2004-2018

\begin{tabular}{|c|c|c|c|c|c|c|c|c|c|c|c|c|c|c|c|}
\hline Region & 2004 & 2005 & 2006 & 2007 & 2008 & 2009 & 2010 & 2011 & 2012 & 2013 & 2014 & 2015 & 2016 & 2017 & 2018 \\
\hline Center & 29.2 & 28.1 & 27.2 & 31.8 & 30.1 & 22.3 & 21.1 & 22.8 & 22.8 & 23.2 & 22.5 & 23.9 & 22.6 & 28.0 & 25.1 \\
\hline North-East & 18.3 & 19.5 & 16.4 & 18.1 & 17.7 & 14.0 & 14.8 & 15.2 & 14.2 & 14.0 & 11.3 & 12.8 & 11.7 & 15.1 & 14.7 \\
\hline North-West & 17.3 & 21.6 & 16.5 & 18.0 & 18.8 & 15.5 & 15.5 & 17.0 & 15.6 & 15.6 & 11.9 & 13.6 & 12.2 & 15.3 & 15.7 \\
\hline South & 22.2 & 22.9 & 19.8 & 23.0 & 21.7 & 16.4 & 18.4 & 19.9 & 20.3 & 20.6 & 16.1 & 17.2 & 16.3 & 22.9 & 23.0 \\
\hline South-East & 16.0 & 17.7 & 14.8 & 16.4 & 17.4 & 14.4 & 14.5 & 16.1 & 14.5 & 14.4 & 11.6 & 12.9 & 12.4 & 15.8 & 17.0 \\
\hline South -West & 16.3 & 19.3 & 14.8 & 16.0 & 16.8 & 13.6 & 14.0 & 15.3 & 13.6 & 13.3 & 11.0 & 12.9 & 11.7 & 14.3 & 14.5 \\
\hline West & 10.5 & 12.1 & 9.6 & 9.8 & 10.7 & 8.9 & 10.0 & 11.8 & 13.1 & 11.7 & 7.5 & 9.4 & 8.9 & 11.5 & 11.1 \\
\hline Total & 14.6 & 16.2 & 13.7 & 14.0 & 13.2 & 10.9 & 10.7 & 12.1 & 11.6 & 12.0 & 9.8 & 10.5 & 10.2 & 13.3 & 13.9 \\
\hline Center & 144.3 & 157.4 & 132.8 & 147.1 & 146.5 & 116.0 & 119.0 & 130.2 & 125.6 & 124.8 & 101.6 & 113.2 & 106.0 & 136.6 & 135.5 \\
\hline
\end{tabular}

Source: Romanian National Trade Register Office, 2021. Statistics. Available at: https://www.onrc.ro/index.php/ro/statistici, [Accessed at 16.08.2021]. 